\title{
AVOIDANCE COPING, CONTINGENT SELF-ESTEEM DAN BELANJA KOMPULSIF
}

\author{
Djudiyah \\ Fakultas Psikologi Universitas Muhammadiyah Malang \\ djudiyah@umm.ac.id
}

\begin{abstract}
Abstrak. Membanjirnya iklan produk fashion di berbagai media dan mudahnya mendapatkan produk pakaian, membuat keputusan berbelanja anak-anak muda lebih didasarkan pada aspek emosi. Keputusan berbelanja seringkali dimaksudkan untuk mendapatkan gengsi atau penghargaan dari orang lain dapat mendorong mereka melakukan belanja kompulsif. Penelitian ini bertujuan untuk mengetahui peran avoidance coping dalam memediasi hubungan antara contingent self-esteem dengan belanja kompulsif pakaian. Subjek penelitian ini berjumlah 276 mahasiswi Universitas Muhammadiyah Malang Angkatan 2018 yang diambil dengan teknik stratified sampling. Instrumen penelitian yang digunakan dalam proses pengumpulan data adalah: skala Contingent Self-esteem (CSE), skala Coping Respon Inventoty (CRI) dan skala belanja kompulsif pakaian. Analisis data dilakukan dengan metode Mediation Analysis dari Hyes menunjukkan bahwa avoidance coping mampu memediasi hubungan antara contingent self-esteem dengan belanja kompulsif yang ditunjukkan dengan $\mathrm{B}=0.322$; dengan $\mathrm{p}=0.006(<0.01)$.
\end{abstract}

Kata Kunci: avoidance coping, contingent self-esteem, belanja kompulsif

\begin{abstract}
The flood of advertisements on fashion products in various media and the ease of getting clothing products, makes the decision to shop for young people more based on emotional aspects. Shopping decisions are often meant to get prestige or appreciation from others, which can encourage them to do compulsive shopping. This study aims to determine the role of avoidance coping in mediating the relationship between contingent self-esteem and compulsive shopping for clothing. The subject of this study amounted to 276 female students at the University of Muhammadiyah Malang Force 2018 taken by stratified sampling technique. The measures used were: Contingent Self-esteem (CSE) scale, Inventory Response Coping scale (CRI) and clothing compulsive shopping scale. Data analysis was performed by the Mediation Analysis method from Hyes showed that avoidance coping was able to mediate the relationship between contingent self-esteem and compulsive spending as indicated by $B=0.322$; with $p=0.006 \quad(<0.01)$.
\end{abstract}

Keywords: avoidance coping, contingent self-esteem, compulsive shopping 
Perkembangan teknologi informasi yang sangat pesat di abad 21 ini berdampak pada semua aktivitas kehidupan manusia, salah satu diantaranya berpengaruh pada perilaku kosumen. Konsumen semakin mudah mendapatkan informasi tentang produk maupun jasa yang dibutuhkan. Melalui internet (toko-toko online) konsumen dapat mencari produk yang diinginkan dan dapat membanding-bandingkan produk atau jasa satu dengan produk atau jasa lainnya. Pakaian merupakan salah poduk yang menjadi minat anak-anak muda, karena mereka sangat peduli dengan penampilannya (Hurlock, 2004). Produsen mampu menawarkan berbagai produk pakaian dikalangan anak-anak muda generasi $\mathrm{Y}$ dan $\mathrm{Z}$ atau generasi melenial dengan beaya murah dan dapat menjangkau semua segmen pasarnya tanpa harus dibebani sewa toko. Hal ini diperkuat riset yang dilakukan Nielsen pada tahun 2017 menunjukkan bahwa jaringan internet yang diakses melalui smartphone merupakan media sosial yang banyak diakses anak-anak muda (Priyadana, 2018).

Maraknya tayangan iklan produk pakaian di internet dan tingginya intensitas anak-anak muda mengakses situs-situs di internet terutama produk pakaian dapat berpengaruh pada pembelanjaan pakaian yang dilakukan. Apalagi anak-anak muda generasi Y dan Z ini tidak pernah lepas dari internet dan smarthphone dalam kehidupan kesehariannya (Shareef, Dwivedi \& Kumar, 2016). Anak-anak muda dengan self-esteem tinggi mampu menilai iklan yang mereka lihat secara proporsional. Mereka mampu berpikir rasional sebelum memutuskan untuk melakukan proses pembelian. Namun bagi anakanak muda yang memiliki self-esteem rendah akan menilai iklan yang dilihat sebagai pembanding penampilannya. Anak-anak muda dengan self esteem rendah menginginkan dirinya sebagaimana penampilan bintang iklan yang dilihatnya (Rath, Bay, Petrizzi \& Gill, 2015).

Pembelian produk pakaian yang dilakukan anak-anak muda dengan self-esteem rendah lebih didorong untuk mendapatkan penampilan diri yang ideal agar citra diri dapat positif (Rath, et al., 2015). Keputusan membeli bukan karena kebutuhan, tapi lebih didasari oleh keinginan sesaat, sekedar mengikuti tren atau menjaga gengsi (Setiana, 2013). Mereka seringkali berbelanja produk di luar jangkauannya atau kemampuan keuangannya, berbelanja produk yang kurang memiliki kegunaan, produk-produk mahal serta suka mengumpulkan produk. Hal ini disebabkan karena ada perasaan bangga ketika mampu memiliki barang yang orang lain belum tentu memilikinya, tidak ingin kalah saingan dengan teman kuliah maupun dengan teman kosnya (Farida, 2011). Pembelanjaan ini biasa disebut dengan belanja kompulsif (Horvath, Adiguzel \& Herk, 2013).

Beberapa riset terdahulu menemukan bahwa anak-anak muda dengan self esteem rendah cenderung melakukan belanja kompulsif (Ridgway, Kukar-Kennay, \& Monroe, 2006; Ureta, 2007; Benson, Dittmar \& Wolfsohn, 2010; Ergin, 2010; Lejoyeox, et al., 2011; Lo, \& Harvey, 2012; Horvath, Adiguzel \& Herk, 2013; Mangestuti, 2014). Anak-anak muda dengan self-esteem rendah merasa bahwa dirinya tidak kompeten dan berharga. Mereka berusaha menemukan rasa berharga atau rasa bermakna dari penerimaan, cinta dan persetujuan orang di sekitarnya terutama dari teman sebayanya (peer group). Mereka berusaha menyeragamkan diri dengan harapan orang sekitarnya untuk mendapatkan rasa berharga, bermakna atau cinta dari orang lain. Perasaan berharga yang bersumber dari orang lain atau eksternal ini juga disebut dengan contingent self-esteem tinggi (Johnson 
\& Blom, 2007). Mereka merasa berharga atau merasa berarti ketika mampu memenuhi harapan orang lain terutama peer groupnya.

Riset Biolcati (2017) pada individu yang berusia 18-60 tahun menemukan bahwa individu dengan contingent self-esteem tinggi cenderung melakukan belanja kompulsif dibanding dengan individu dengan contingent self-esteem rendah. Penelitian ini sebenarnya hampir sama dengan penelitian terdahulu yang mencoba mengkaji antara self-esteem dengan belanja kompulsif (Liu \& Laird, 2008; Mangestuti, 2014). Individu dengan self-esteem rendah atau individu dengan contingent self-esteem tinggi cenderung melakukan belanja kompulsif. Hal ini disebabkan karena sumber perasaan berharga atau bermakna tergantung pada penerimaan, cinta atau persetujuan orang lain.

Patrick, Neighbors \& Knee (2004) dan Shrestha (2013) menemukan bahwa mahasiswi dengan self-esteem rendah lebih suka membandingkan penampilannya dengan model iklan, mengalami lebih besar pengurangan afek positif, lebih banyak mengamati dan mengevaluasi kondisi fisik (body) nya dan malu pada beberapa kondisi. Mereka cenderung menggunakan avoidance coping dalam mengatasi permasalahannya (Undheim \& Sund, 2017; McNicol \& Thorsteinsson, 2017). Ketika mereka merasa kurang mendapatkan penghargaan dari teman, mereka berusaha menghindar untuk mereduksi kecemasan yang dialaminya (McNicol \& Thorsteinsson, 2017).

Riset Servidioa, Ambra \& Bocab (2018) dan McNicol \& Thorsteinsson (2017) menemukan bahwa mahasiswa dengan harga diri rendah atau memiliki contingent self-esteem tinggi rentan mengalami adiksi internet. Strategi avoidance coping mampu memediasi hubungan antara self-esteem dengan adiksi internet. Meski riset ini tentang adiksi internet, namun pada prinsipnya konsep teori yang digunakan adalah terori obsessive compulsive. Berdasarkan hasil riset ini peneliti berasumsi bahwa avoidance coping yang dimiliki individu dapat memperkuat hubungan antara contingent self-esteem dengan belanja kompulsif pada mahasiswa.

Riset yang dilakukan pada 300 mahasiswa Universitas Italia menemukan bahwa ada hubungan negatif antara harga diri dengan resiko adiksi internet. Strategi coping menghindar mampu memediasi hubungan antara self-esteem dengan resiko adiksi internet (Servidioa, Ambra Gentileb, \& Bocab, 2018). Berdasarkan temuan ini, peneliti berasumsi bahwa ada hubungan positif antara contingent self-esteem dengan belanja kompulsif pakaian dengan strategi coping menghindar (avoidance coping) sebagai variabel mediasi. Anakanak muda dengan contingent self-esteem tinggi memiliki resiko tinggi untuk melakukan belanja kompulsif pakaian, terutama ketika mereka memiliki intensitas tinggi dalam menggunakan strategi coping menghindar ketika dihadapkan pada permasalahan.

Beberapa penelitian terdahulu menemukan bahwa anak-anak muda yang suka berbelanja secara kompulsif kurang termotivasi dengan penyelesaian studinya. Mereka asyik dengan berbelanja, browshing produk di toko online dan kurang tertarik dengan aktivitas yang melibatkan tantangan intelektual, hobi, memelihara serta meningkatkan kreativitasnya. Banyak waktunya digunakan untuk mencari uang untuk berbelanja secara kompulsif dibanding dengan upaya pengembangan dirinya sehingga mengganggu proses pencapaian masa depannya. Mereka juga cenderung mengalami kekosongan spiritual sebagai akibat dari overshopping yang dilakukannya. Mereka beresiko kehilangan 
hubungan dekat dengan keluarga, masyarakat dan alam (Kasser, 2002; Schwartz, 2004). Kebanyakan dari mereka memiliki kesadaran rendah pada pertumbuhan being more (Benson, Dittmar \& Wolfsohn, 2010).

Belanja kompulsif merupakan dorongan yang sangat kuat untuk berbelanja yang tidak dapat ditahan, kehilangan banyak kontrol dalam perilaku berbelanja serta terus menerus melakukan pembelanjaan meskipun akibatnya merugikan atau berlawanan dengan kehidupan personal, sosial, kehidupan pekerjaannya maupun hutang finansial (Dittmar, 2004; 2005). Belanja kompulsif dilakukan untuk menunjukkan identitas dirinya pada orang lain serta untuk mengurangi kesenjangan antara self yang riil dan self yang ideal. Dengan demikian, belanja kompulsif dipertimbangkan sebagai gangguan mengontrol dorongan (Dittmar, 2004; Billieux, et al., 2008).

Menurut Dittmar (2004; 2005) ada tiga dimensi belanja kompulsif, yaitu:

1) Dorongan yang sangat kuat

Dorongan yang sangat kuat merupakan dorongan atau keinginan yang sangat kuat untuk melakukan pembelanjaan yang hadir terus menerus dalam pikiran.

2) Kehilangan kontrol

Kehilangan kontrol merupakan ketidakmampuan menghentikan keinginan dan dorongan yang sangat kuat untuk berbelanja.

3) Konsekwensi yang merugikan.

Belanja kompulsif mengakibatkan kerugian yang bersifat personal, sosial, pekerjaan dan hutang finansial.

Ureta (2007) menyatakan ada beberapa faktor yang menjadi penyebab terjadinya belanja kompulsif, yaitu:

1) Ketidakstabilas emosi (emotional instability)

Individu yang memiliki emosi yang tidak stabil mudah terpengaruh oleh lingkungan sekitarnya. Individu akan mencari cara untuk meredam emosinya dengan cara melakukan pembelanjaan kompulsif

2) Kepribadian Individu dengan self-esteem rendah atau memiliki inferriority feeling tinggi cenderung melakukan belanja kompulsif.

4) Nilai-nilai (values) yang diinternalisasi individu.

Individu dengan nilai materialistic tinggi cenderung melakukan belanja impulsif, karena tujuan hidup dan ukuran kesuksesan adalah banyaknya materi yang dimilikinya.

5) Ketidakmampuan mengontrol diri

Individu yang tidak mampu mengontrol dirinya cenderung melakukan belanja kompulsif. Mereka mudah terbujuk oleh bujukan iklan atau pengaruh model.

6) Latarbelakang keluarga.

Keluarga yang menjadikan standar kesuksesan dalam hidupnya adalah materi dapat membuat anak-anaknya juga berorientasi pada materi, sehingga mereka seringkali melakukan pembelanjaan kompulsif. Anak-anak akan memodel orang tuanya dalam melakukan pembelanjaan secara kompulsif. 
7) Krisis hubungan suami istri

Hubungan suami istri yang tidak harmonis yang dialami dalam kurun waktu yang lama dapat menghasilkan distress psikologis. Sebagai akibatnya istri akan mereduksi ketegangan yang dialami dengan melakukan pembelanjaan yang berlebihan.

Contingent self-esteem didefinisikan sebagai interpretasi seseorang bahwa dirinya berharga. Perasaan berharga ini tergantung pada penilaian seseorang tentang keberhasilan dan kegagalan yang bersumber dari faktor eksternal, misalnya: keinginan untuk dicintai orang lain, keinginan diterima oleh orang lain, menginginkan diri sempurna (perfect pada diri sendiri), keinginan untuk memenuhi harapan orang lain (Johnson \& Blom, 2007).

Perasaan berharga pada individu dengan contingent self-esteem tinggi diperoleh tergantung pada sejauhmana orang lain atau kelompok memberikan persetujuan terhadap keberhasilan yang dicapai. Dengan demikian, dapat dikatakan bahwa perasaan kompeten pada diri mereka terbentuk dengan persyaratan tertentu (unconditional competence) dari lingkungan sosialnya. Sebagai akibatnya individu dengan contingent self-esteem tinggi sering merasa frustrasi, mengkritik diri sendiri dan berjuang untuk mendapatkan perasaan kompeten dari orang lain. Individu berusaha berjuang untuk mendapatkan cinta bersyarat, takut ditolak dan patuh pada standar orang lain atau kelompok (Johnson \& Blom, 2007).

Menurut Johnson \& Blom (2007) ada 2 dimensi contingent self-esteem ada 2, yaitu:

1) Kompeten (competence base self-esteem)

Kompeten diartikan sebagai merasa mampu atau merasa mendapatkan prestasi, status maupun kesempurnaan (perfect) dalam hubungan interpersonal. Hal ini membuat orang mengkritik diri sendiri, ambisius, mengontol atau agresif dalam hubungan interpersonal.

a. Contingent upon competence

Merasa kompeten, berprestasi, mendapatkan status tergantung pada penilaian orang lain

b. Self-critical

Mengkritik diri sendiri dan mengharapkan diri sempurna

2) Hubungan dengan orang lain (relations based self-esteem)

Kecenderungan individu untuk mendukung menenteramkan hati terus menerus untuk kelekatan pada orang lain disamping perasaan berguna atau bermanfaat.

a. Rejection

Menghindari penolakan orang lain

b. Contingent upon love

Tergantung dengan cinta dari orang lain

c. Compliance

Patuh pada harapan orang lain.

Coping didefinisikan sebagai usaha kognitif dan perilaku yang dilakukan terus menerus untuk mengelola tuntutan lingkungan eksternal maupun internal yang spesifik yang dinilai melebihi sumberdaya seseorang (Lazarus, 1993). Individu berusaha memberikan respon baik secara kognitif maupun perilaku terus menerus ketika dihadapkan pada tuntutan lingkungan (stressor) yang berada diatas kapasitas yang dimilikinya. 
Beberapa ahli memiliki pandangan yang berbeda tentang strategi coping atau cara orang merespon tuntutan (stressor) lingkungannya. Lazarus (1993) membagi strategi coping menjadi 8 macam, yaitu : confrontive coping, distancing, self-controlling, seeking social support, accepting responsibility, escape-avoidance, planful problem-solving serta positive reappraisal. Setelah dikaji ulang ternyata ke delapan macam strategi coping ini dapat diklasifikasikan menjadi 2 strategi, yaitu: problem focus coping dan emotion focus coping.

Moos (2004) menyatakan bahwa pada strategi problem focus coping, individu berusaha secara kognitif maupun perilaku untuk mengatasi persoalan atau tuntutan kehidupan yang dialami melebihi kapasitas yang dimilikinya. Namun pada emotion focus coping, individu berusaha untuk memberikan respon baik secara kognitif maupun perilaku dengan cara berpikir menjauh dari stressor dan sebagai implikasinya berusaha mengelola stressor berdasar emosinya. Berdasarkan pandangan ini, Moos (2004) membagi coping menjadi 2 macam, yaitu: approach respon an avoidance respon.

Moos (2004) membagi strategi coping menjadi 2 yaitu, approach coping dan avoidance coping, dimana tiap-tiap strategi coping memiliki dua dimensi yaitu:

1) Approach coping responses

a. Kognitif.

Individu berusaha menganalisis secara logis terhadap persoalan hidup yang dialaminya dan berusaha menilainya kembali secara positif.

b. Behavioral

Individu berusaha mencari petunjuk dan support untuk melakukan problem solving

2) Avoiding coping responses

a. Kognitif

Individu berusaha menghindar secara kognitif atau menolak untuk berpikir logis terhadap persoalan yang dialami dan menerimanya dengan pasrah (pengunduran diri).

b. Behavioral

Individu berusaha mencari alternatif reward dan mengeluarkan/menyalurkan emosi

Meskipun Moos (2004) menyusun skala strategi coping menjadi 2, namun pada penelitian ini hanya digunakan item-tem yang mengukur avoidance coping saja dengan pertimbangan bahwa tujuan dari penelitian ini hanya ingin mengetahui avoidance coping.

Teman sebaya (peer group) berpengaruh besar terhadap kehidupan anak-anak muda (Hurlock, 2004). Anak-anak muda cenderung membandingkan diri dengan peer groupnya, karena peer merupakan sumber norma, sikap dan nilai personal bagi mereka (Childers \& Rao, 1992). Studi menunjukkan bahwa komunikasi atau kedekatan hubungan interpersonal dengan peer berpengaruh pada motivasi sosial anak-anak muda untuk mengkonsumsi serta menggunakan peer sebagai rujukan dalam memilih produk (Liu \& Laird, 2008; Lee \& Park, 2008).

Anak-anak muda yang cenderung membandingkan dirinya dengan orang lain terutama peer groupnya akan tidak menguntungkan bagi perkembangan self-esteemnya (Chan \& Zhang, 2007). Mereka hanya akan merasa berharga ketika mereka berperilaku sesuai 
dengan harapan kelompoknya. Mereka lebih rentan dipengaruhi oleh peer karena mereka sedang mencari definisi tentang diri sebagai individu atau sedang melakukan eksplorasi diri untuk menemukan identitas diri (Sharma, Raciti, O'Hara \& Reinhard, 2013). Rendahnya self-esteem ini juga dapat disebut dengan contingent self-esteem tinggi. Mereka hanya akan merasa berharga ketika mereka mampu memenuhi harapan atau menyeragamkan diri dengan standar atau keinginan orang lain atau kelompoknya (Biolcati, 2017).

Anak-anak muda dengan contingent self-esteem tinggi akan merasa berharga ketika mereka mampu mendapatkan prestasi, status atau mampu berpenampilan sempurna (perfect) berdasarkan standar perilaku orang lain atau teman sebayanya. Mereka khawatir mendapatkan penolakan orang lain, mengharapkan cinta dari orang lain, sehingga mereka cenderung patuh dengan apa yang diharapkan oleh kelompoknya. Dengan demikian, anak-anak muda dengan contingent self-esteem tinggi lebih dipengaruhi oleh faktor yang bersifat eksternal. Namun sebaliknya, anak-anak muda dengan contingent self-esteem rendah akan merasa berharga ketika mereka mampu mengembangkan potensinya. Mereka mampu mengevaluasi dirinya secara objektif sehingga mereka mampu menerima dirinya secara proporsional. Dengan demikian, anak-anak muda dengan contingent selfesteem rendah lebih dipengaruhi oleh faktor yang bersifat internal dalam mendapatkan perasaan berharganya (Biolcati, 2017).

Anak-anak muda memiliki perhatian besar dengan penampilannya. Penampilan yang menarik dapat mensupport mereka dalam berinteraksi dengan orang lain terutama peer groupnya (Hurloock, 2004). Mereka cenderung berafiliasi dengan teman yang memiliki atribut yang sama atau memiliki beberapa kesamaan (Ryan, 2001). Mereka berusaha menggunakan opini teman dalam memutuskan pembelanjaan (Lee \& Park, 2008). Mereka berusaha untuk menggunakan standar peer groupnya sebagai acuan dalam berbelanja terutama pada anak-anak muda dengan contingent self-esteem tinggi. Mereka berusaha berbelanja produk sesuai dengan standar kelompoknya, mengevaluasi dirinya secara kritis, ingin tampil perfect dalam setiap situasi. Hal ini dimaksudkan agar dirinya mendapatkan perhatian, penerimaan, penghargaan dan cinta dari orang lain (Johnson \& Blom, 2007; Biolcati, 2017). Dengan demikian, anak-anak muda dengan contingent selfesteem tinggi mengaharapkan dirinya senantiasa berpenampilan yang atraktif, mendapatkan penerimaan, memiliki power, serta ingin selalu sukses dalam interaksi sosial (Patrick, Neighbors \& Knee, 2004). Harapan-harapan terhadap diri yang demikian ini akan mendorong mereka melakukan belanja kompulsif (Mangestuti, 2014; Biolcati, 2017) baik melalui toko konvensional maupun toko online (Dittmar, Long \& Bond, 2007).

Anak-anak muda yang memiliki strategi avoidance coping tinggi cenderung menjauhkan diri dari pikiran dan perilakunya untuk mengatasi tuntutan lingkungan yang menekan dirinya (Moos, 2004). Mereka berusaha mencari aktivitas pengganti, menarik diri dan menjauhi sumber stress, pasif dalam merespon sumber stress, merasa tidak berdaya dan tidak memiliki harapan dengan permasalahan yang dialaminya (Lazarus, 1993; OteroLopes \& Villardefracos, 2014 ;Dziurzyńska, Pawłowska \& Potembska, 2016). Individu cenderung melakukan belanja kompulsif sebagai upaya untuk menjauhkan diri dari tuntutan lingkungan sekitarnya yang menekan serta mengalihkan pikiran untuk menjauhkan diri dari stressor kehidupan (Otero-Lopes \& Villardefracos, 2014). 
Anak-anak muda dengan contingent self-esteem tinggi cenderung menggunakan avoidance coping dalam mengatasi persoalan yang dialaminya (Shrestha, 2013). Mereka cenderung membanding-bandingkan penampilannya dengan teman-temannya. Ketika mereka merasa tidak mampu menampilkan dirinya secara atraktif, mereka akan merasa cemas, merasa takut ditolak orang lain terutama teman-temannya (Crocker \& Park, 2004). Perasaan negatif yang dialami ini membuat mereka menarik diri (withdrawl) dari teman-temannya, menerima dengan tidak berdaya (Lazarus, 1993) atau melakukan pembelanjaan kompulsif. Belanja kompulsif dimaksudkan sebagai upaya untuk mengatasi persoalan yang dialaminya (Otero-Lopes \& Villardefracos, 2014) atau sebagai cara untuk mengatasi kecemasan dan perasaan tertekan (stress) yang dialami (Dziurzyńska, Pawłowska \& Potembska, 2016). Mereka memiliki motivasi tinggi untuk menyeragamkan diri dengan teman-temannya dalam berpakaian. Mereka berusaha untuk mendapatkan produk pakaian yang sedang trend dan dipakai teman-temannya. Dengan demikian, anak-anak muda dengan contingent self-esteem tinggi cenderung melakukan belanja kompulsif, apalagi bila mereka juga memiliki strategi avoidance coping tinggi

Berdasarkan paparan diatas dapat disimpulkan bahwa anak-anak muda dengan contingent self-esteem tinggi mengharapkan dirinya selalu kompeten dan tampil perfect dalam segala situasi. Mereka berusaha memenuhi harapan atau tuntutan peer groupnya, khususnya dalam berpakaian. Mereka berusaha keras mengikuti perkembangan mode pakaian yang sedang trend. Mereka akan mencari informasi tentang produk pakaian baik melalui toko konvensional maupun online dan melakukan belanja kompulsif. Hal ini dimaksudkan agar mereka mendapatkan pujian dan penerimaan dari orang lain, memiliki kekuasaan (power), selalu tampil sukses dalam segala situasi, sehingga mereka merasa berharga. Perilaku berbelanja semacam ini akan membentuk pola dan akan dilakukan kembali ketika mereka dihadapkan pada stressor kehidupan lain dimasa yang akan datang. Apalagi ketika anak-anak muda memiliki strategi coping avoidance tinggi, maka mereka juga akan semakin tinggi belanja kompulsifnya. Belanja kompulsif pakaian dimaksudkan untuk menjauhkan diri dari pikiran dan perilaku dari tuntutan lingkungann yang menekannya. Belanja kompulsif pakaian dijadikan sebagai aktivitas pengganti yang menyenangkan.

Penelitian ini memiliki tiga tujuan penelitian, yaitu: (1) untuk mengetahui hubungan antara contingent self-esteem dengan belanja kompulsif; (2) untuk mengetahui hubungan antara contingent self-esteem dengan avoidance coping; (3) untuk mengetahui Avoidance coping memediasi hubungan antara contingent self-esteem dengan belanja kompulsif. Penelitian ini bermanfaat untuk mengembangkan teori psikologi konsumen yang masih relatif terbatas, khususnya pengembangan teori belanja kompulsif. Hasil penelitian ini juga dapat digunakan sebagai dasar untuk melakukan upaya prevensi maupun kurasi terhadap fenomena belanja kompulsif, khususnya dikalangan mahasiswi. 


\section{METODE PENELITIAN}

Penelitian ini merupakan penelitian kuantitatif korelasional (Suryabrata, 2012). Peneliti ingin mengetahui hubungan antara contingent self-esteem dengan belanja kompulsif pakaian yang dimediasi oleh avoidance coping.

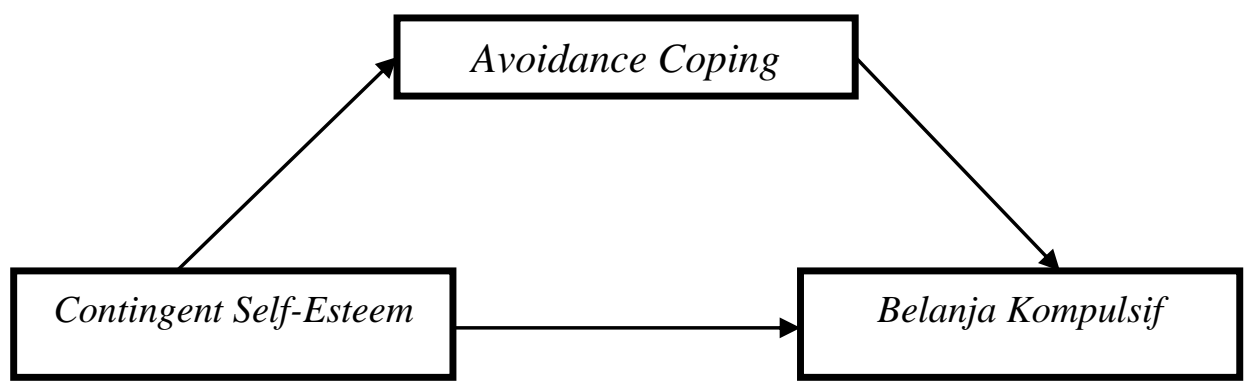

Gambar 1. Desain Penelitian

Populasi pada penelitian ini adalah mahasiswi Universitas Muhammadiyah Malang Angkatan Tahun 2018. Sedangkan sampel pada penelitian ini berjumlah 276 mahasiswi yang diambil dengan teknik stratified sampling (Neuman, 2000).

Terdapat tiga variabel pada penelitian ini yaitu: contingent self-esteem sebagai variabel bebas, avoidance coping sebagai variabel mediasi dan belanja kompulsif pakaian sebagai variabel tergantung. Metode pengumpul data pada penelitian ini adalah skala. Ada 3 skala yang digunakan dalam penelitian ini yaitu, Skala Contingent Self-Esteem (CSE), skala avoidance coping (CRI), serta skala belanja kompulsif.

Skala Contingent Self-Esteem (CSE) disusun oleh Johnson dan Blom (2007). Ada 2 aspek atau dimensi contingent self-esteem yaitu competence based self-esteem dan relation based self-esteem. Skala contingent self-esteem disusun sebanyak 26 item, yang terdiri dari 12 item untuk aspek competence based self-esteem dan 14 item untuk aspek relation based self-esteem. Uji coba skala contingent self-esteem yang dilakukan peneliti pada 91 mahasiswa Fakultas Psikologi Universitas Muhammadiyah Malang, angkatan 2017 menemukan bahwa dari 26 item, ada 22 item yang dinyatakan valid dan ada 4 item yang dinyatakan tidak valid. Angka validitasnya bergerak dari $r=0.347-0.661$ dan koefisien reliabilitas sebesar $\alpha=0.900$. Dua puluh tiga item yang dinyatakan valid inilah yang digunakan untuk penelitian.

Avoidance coping diukur menggunakan skala Coping Respon Inventory (CRI) yang disusun oleh Moos (2004) sebanyak 48 item. Ada 24 item untuk mengukur approach coping dan ada 14 item untuk mengukur avoidance coping. Uji coba skala avoidance coping yang dilakukan pada 91 mahasiswa Fakultas Psikologi Universitas Muhammadiyah Malang, Angkatan tahun 2017 menemukan bahwa dari 14 item, ada 11 item yang dinyatakan valid dan ada 3 item yang dinyatakan tidak valid. Angka validitasnya bergerak dari 0.325 sampai 0.573 dan koefisien reliabilitas sebesar $\alpha=$ 0.794. Sebelas item yang dinyatakan valid inilah yang akan digunakan untuk mengambil data penelitian. Skala contingent self-esteem dan avoidance coping disusun dalam bentuk 
skala Likert dengan lima alternatif jawaban, yaitu : Sangat Sesuai (SS), Sesuai (S), Cukup Sesuai (CS), Tidak Sesuai (TS) dan Sangat Tidak Sesuai (STS) (Azwar, 2012).

Skala belanja kompulsif disusun berdasar teori Dittmar (2005). Ada 3 aspek belanja kompulsif yaitu dorongan yang sangat kuat untuk melakukan pembelanjaan, dorongan berbelanja yang sulit dikendalikan dan konsekwensi yang merugikan. Skala ini disusun sebanyak 28 item dengan angka validitas bergerak dari 0.308 sampai 0.750 dengan koefisien reliabilitas sebesar $\alpha=0.902$. Skala belanja kompulsif pakaian disusun dalam bentuk skala Likert dengan lima alternatif jawaban, yaitu : Selalu (SL), Sering (S), Terkadang (KDG), Jarang (J) dan Tidak Pernah (TP).

Metode analisis data yang digunakan pada penelitian ini adalah Mediation Analysis dari Hyes. Metode ini dimaksudkan untuk mengetahui hubungan antara contingent selfesteem dengan belanja kompulsif pakaian dan avoidance coping dalam memediasi hubungan antara contingent self-esteem dengan belanja kompulsif pakaian. Analisis data pada penelitian ini dilakukan dengan bantuan program SPSS v.21.

\section{HASIL PENELITIAN}

Hasil uji hubungan antara contingent self-esteem dengan belanja kompulsif pakaian sebagaimana tabel berikut:

\section{Tabel 1.}

Hasil Uji Hubungan Antara Contingent Self-esteem Dengan Belanja Kompulsif Pakaian

\begin{tabular}{lcc}
\hline \multicolumn{1}{c}{ Model } & B & Sig. \\
\hline $\begin{array}{l}\text { Variabel X } \\
\text { terhadap Y }\end{array}$ & 0.686 & $0.000(\mathrm{p}<0.01)$ \\
\hline
\end{tabular}

Dari Tabel 1. menunjukkan terdapat hubungan positif yang sangat signifikan antara contingent self-esteem dengan belanja kompulsif pakaian pada mahasiswi yang ditunjukkan dengan $\mathrm{B}=0.686$, dengan $\mathrm{p}=0.000(<0.01)$. Dengan demikian, hipotesis yang menyatakan ada hubungan positif antara contingent self-esteem dengan belanja kompulsif pakaian pada penelitian ini, diterima.

Tabel 2.

Hasil Uji Hubungan Antara Contingent Self-esteem Dengan Avoidance Coping

\begin{tabular}{lcc}
\hline \multicolumn{1}{c}{ Model } & B & Sig. \\
\hline Variabel X & 0.459 & $0.000(\mathrm{p}<0.01)$ \\
terhadap M & & \\
\hline
\end{tabular}


Tabel 2. menunjukkan terdapat hubungan positif yang sangat signifikan antara contingent self-esteem dengan coping menghindar (avoidance coping) yang ditunjukkan dengan $\mathrm{B}=0.459$; dengan $\mathrm{p}=0.000(<0.01)$. Artinya, semakin tinggi contingent self-esteem yang dimiliki mahasiswi maka mahasiswi memiliki kecenderungan untuk menggunakan coping menghindar ketika dihadapkan pada sebuah persoalan kehidupan.

Tabel 3.

Hasil Uji Hubungan Antara Contingent Self-esteem Dengan Belanja Kompulsif Pakaian yang Dimediasi oleh Avoidance Coping

\begin{tabular}{lcc}
\hline Model & B & Sig. \\
\hline Variabel X terhadap Y dan & 0.539 & $0.000(\mathrm{p}<0.01)$ \\
M & 0.322 & $0.000(\mathrm{p}<0.01)$ \\
\hline
\end{tabular}

Tabel di atas menunjukkan bahwa coping menghindar (avoidance coping) mampu memediasi hubungan antara contingent self-esteem dengan belanja kompulsif pakaian pada mahasiswi yang ditunjukkan dengan $\mathrm{B}=0.322$; dengan $\mathrm{p}=0.006(<0.01)$. Dengan demikian, hipotesis yang menyatakan bahwa avoidance coping mampu memediasi hubungan antara contingent self-esteem dengan belanja kompulsif pakaian pada mahasiswi, diterima.

\section{DISKUSI}

Hasil penelitian menunjukkan bahwa ada hubungan positif dan sangat signifikan antara contingent self-esteem dengan belanja kompulsif pakaian pada mahasiswi. Mahasiswi dengan contingent self-esteem tinggi memiliki kecenderungan tinggi untuk melakukan belanja kompulsif pakaian. Hasil penelitian ini mendukung hasil riset Mangestuti (2014) yang menemukan bahwa mahasiswa dengan self-esteem rendah cenderung melakukan belanja secara kompulsif. Mahasiswi dengan contingent self-esteem tinggi memiliki keinginan atau dorongan yang sangat kuat untuk mendapatkan penghargaan dari orangorang sekitarnya, karena perasaan berharganya sangat ditentukan oleh reaksi positif orang lain terhadap dirinya, khususnya penampilannya (appearance).

Riset Dittmar \& Drury (2000) menemukan bahwa wanita berbelanja lebih didorong oleh adanya ketakutan sangsi sosial atau masyarakat dan budaya yang berlaku, khususnya berbelanja pakaian. Banyaknya iklan dan mudahnya mengakses produk fashion di media sosial ini semakin menguatkan kecenderungan mahasiswi untuk melakukan pembelanjaan secara kompulsif (Dittmar, Long, \& Bond, 2007). Mahasiswi yang memiliki contingent self-esteem tinggi cenderung memonitor dan membandingkan dirinya khususnya penampilannya, karena pakaian dapat menyimbolkan citra diri atau merupakan presentasi dirinya. Mereka cenderung memantau produk fashion yang sedang trend, agar mereka mampu menjadi pemakai pakaian fashion pemula. Reaksi positif atau reinforcement positif dari orang di sekitarnya ini merupakan sebuah prestasi yang membanggakan.

Hasil penelitian juga menemukan bahwa mahasiswi dengan contingent self-esteem tinggi cenderung menggunakan strategi coping menghindar (avoidance coping) ketika 
dihadapkan pada persoalan kehidupan. Riset yang dilakukan Otero-Lopes \& Villardefracos (2014) menemukan bahwa strategi coping yang mereka gunakan adalah passive-avoidance dengan tujuan untuk menghindari problerm, impian khayal, mengkritik diri sendiri, menarik diri dari orang lain, dan memiliki skor rendah pada strategi active-focus dalam pemecahan masalah dan menyusun kembali pikirannya (cognitive restructuring). Hal ini mengindikasikan bahwa rasa khawatir terhadap reaksi negatif orang lain terhadap dirinya ini mendorong mereka untuk memenuhi harapan orang sekitarnya.

Penelitian ini juga menemukan bahwa avoidance coping mampu memperkuat hubungan antara contingent self-esteem dengan kecenderungan melakukan belanja kompulsif pakaian. Hal ini menunjukkan bahwa mahasiswi dengan contingent self-esteem tinggi memiliki kecenderungan melakukan belanja kompulsif. Apalagi ketika mereka juga cenderung menggunakan strategi avoidance coping dalam mengatasi permasalahan, maka mereka cenderung memiliki dorongan yang sangat kuat untuk melakukan pembelanjaan secara kompulsif. Hasil penelitian juga menemukan bahwa avoidance coping mampu memediasi hubungan contingent self-esteem dengan belanja kompulsif pakaian secara parsial. Belanja kompulsif pakaian merupakan cara anak-anak muda untuk mengatasi persoalan atau distress yang dialami. Ketika mereka sedang jenuh dengan aktivitas kampus atau sedang mengalami distress psikologis, mereka cenderung melakukan pembelanjaan kompulsif pakaian. Hasil penelitian ini juga mendukung temuan Otero-Lopes \& Villardefracos (2014) bahwa belanja kompulsif ini merupakan cara untuk mengatasi distress psikologis yang dialami.

\section{SIMPULAN DAN IMPLIKASI}

Hasil penelitian menunjukkan bahwa mahasiswi dengan contingent self-esteem tinggi atau memiliki harga diri (self-esteem) rendah cenderung melakukan pembelanjaan kompulsif pakain. Belanja kompulsif pakain yang dilakukan bertujuan untuk mendapatkan perasaan berharga dari reaksi positif orang lain. Kecenderungan belanja kompulsif ini juga akan semakin tinggi ketika cara mendekati permasalahan yang dimiliki avoidance coping. Ketika mereka dihadapkan problem kehidupan mereka cenderung melarikan diri dari permasalahan dengan melakukan pembelanjaan.

Berdasarkan temuan di atas, maka Pengelola Universitas Muhammadiyah Malang yang berperan mengembangkan aktivitas ekstra kurikuler mahasiswa dapat menyusun program ekstrakurikuler, pelatihan problem solving atau sejenisnya yang menarik. Mahasiswi dapat belajar mengelola keuangan dan banyak melibatkan diri dalam aktivitas positif yang dapat mengembangkan potensinya. 


\section{REFERENSI}

Azwar, S. (2012). Penyusunan Skala Psikologi. Yogyakarta: Pustaka Pelajar.

Benson, A.L., Dittmar, H.E.\& Wolfsohn, R. (2010). Compulsive buying: cultural contributors and consequences in impulse control disorders: a clinical guide. London: Cambridge University Press.

Biolceti, R. (2017). The role of self-esteem and fear of negative evaluation in compulsive buying. Frontiers in Psychiatry, 8 (74), 1-8. Doi: 10.3389/fpsyt.2017.00074

Billieux, J., Rochat, L., Rebetez, M.M.L. dan Linden, M.V.D. (2008). Are all facets of impulsivity releted to self-reported compulsive buying behavior?.Personality and Individual Differences, 44, 1432-1442. Doi:10.1016/j.paid.2007.12.011

Chan, K. \& Zhang, C. (2007). Living in a celebrity-mediated social world: The Chinese experience. Young Consumers, 8 (2), 139-152

Childers, T.L. \& Rao, A.R. (1992). The influence familial and peer-based refference groups on consumer decision. Journal of Consumer Research, 19, 198-211.

Chivaneh, M. (2013). The examination of reliability and validity of coping responses inventory among Iranian students. 3rd World Conference on Psychology, Counselling and Guidance (WCPCG-2012). Procedia - Social and Behavioral Sciences 84, $607-614$

Dittmar, H. dan Drury, J. (2000). Self-image - is it in the bag? a qualitative comparison between "ordinary" and "excessive consumers". Journal of Economic Psychology, $21,109-142$

Dittmar, H. (2004). Are you what you have?consumer society . The Psychologist, 17 (4), 206-211.

Dittmar, H. (2005). Compulsive buying - a growing concern? An examination of gender, age, and endorsement of materialistic values as predictors. British Journal of Psychology, 96, 467-491. Doi: 10.1348/000712605x535333

Dittmar, H., Long, K. \& Bond, R. (2007). When a better self is only a button click away: associations between materialistic values, emotional and identity-related buying motives, and compulsive buying tendency online. Journal of Social and Clinical Psychology, 26 (3), 334-361. Doi: 10.1521/jscp.2007.26.3.334

Djudiyah. (2017). Pengaruh nilai materialistik dan kepribadian neurotik terhadap belanja kompulsif dengan faktor moderasi kebersyukuran kepada Tuhan. Disertasi. Bandung: Fakultas Psikologi Universitas Padjadjaran. 
Dziurzyńska, E., Pawłowska, B. \& Potembska, E. (2016). Coping strategies in individuals at risk and not at risk of mobile phone addiction. Curr Probl Psychiatry, 17 (4), 250-260. Doi: 10.1515/cpp-2016-0024

Ergin, E.A. (2010). Compulsive buying behavior tendencies: the case of Turkish consumer. African Journal of Bussiness Management, 4 (3), 333-338.

Farida, I. (2011). Perilaku konsumtif mahasiswa yang tinggal indekost. Skripsi. Jakarta: Fakultas Psikologi Universitas Gunadarma. http://library.gunadarma.ac.id/repository/view/319549/perilaku-konsumtifmahasiswa-yang-tinggal-indekost.html/

Horvath, C., Adiguzel, F. \& Herk, H.V. (2013). Cultural aspects of compulsive buying in emerging and developed economies: a cross cultural study in compulsive buying. Organization and Market in Emerging Economies, 4 (2), 8-24.

Hurlock, E.B. (2004). Developmental psychology. A life-span approach (Terjemahan). Fifth Edition. New York: McGraw-Hill, Inc.

Johnson, T. \& Attmann, J. (2009). Compulsive buying in a product specific contect: clothing. Journal of Fashion Marketing and Management, 13 (3), 394-405. Doi:10.1108/13612020910974519

Johnson, M. \& Blom, V. (2007). Development and validation of two measures of contingent self-esteem. Individual Differences Research, 5 (4), 300-328.

Lazarus, R. S. (1993). Coping theory and research: past, present and future. Psychosomatic Medicine, 55, 234-247.

Lejoyeox, M., Benhaim, C.R., Betizeau, A., Lequen, V. \& Lohernhardt, H. (2011). Money attitude, self-esteem, and compulsive buying in a population of medical students. Frontiers in Psychiatry, 2 (13), 1-5. Doi:10.3389/fpsyt.2011.00013

Lee, Y. J., \& Park, J. K. (2008). The mediating role of consumer conformity in ecompulsive buying. Advances in Consumer Research, 35, 387-392.

Liu, C. \& Laird, R. (2008). Parenting, peer influence, and role model on compulsive buying tendencies of early adolescent consumers. Advances in Consumer Research, 35, 1037-1038. http://www.acrwebsite.org/volumes/v35/naacr_vol35_465.pdf

Lo, H. \& Harvey, N. (2012). Effects of shopping addiction on consumer decision making: web-based studies in real time. Journal of Behavioral Addiction (In Press), $1-28$. 
Mangestuti, R. (2014). Model pembelian kompulsif pada remaja. Disertasi. Yogyakarta: Program Doktor Psikologi Fakultas Psikologi Universitas Gadjah Mada.

McNicol, M. L. \& Thorsteinsson, E. B. (2017). Internet addiction, psychological distress, and coping responses among adolescents and adults. Cyberpsychology Behavior and Social Networking. 20 (5), 296-303. Doi: 10.1089/cyber.201

Moos, R. H. (2004). Coping responses inventory: an update on research applications and validity. Odessa. FL: Psychological Assessment Resources.

Neuman, W.L. (2000). Social research methods. Qualitative and Quantitative Approaches. Fourth Edition. Boston: Allyn and Bacon.

Otero-Lopes, J.M. \& Villardefracos, C. (2014). Prevalence, sociodemographic factors, psychological distress, and coping strategies related to compulsive buying: a cross sectional study in Galicia, Spain. BMC Psychiatry, 14, 1-12. Doi:101186/1471-244x-14-101

Patrick, H., Neighbors, C., \& Knee, C. R. (2004). Appearance-related social comparisons: the role of contingent self-esteem and self-perceptions of attractiveness. Personality and Social Psychology Bulletin, 30 (4), p. 501-514. Doi: 10.1177/0146167203261891

Priyadana, A. (2018). Perilaku konsumen digital Indonesia. https://marketing.co.id/perilaku-konsumen-digital-indonesia/

Rath, P. M, Bay, S. Petrizzi, R., \& Gill, P. (2015). The why of the buy. Consumer behavior and fashion Marketing. New York: Fairchild Books, Inc.

Ridgway, N.M., Kukar-Kennay, M. \& Monroe, K.B. (2006). New perspective on compulsive buying: its roots, measurement and Physiology. Advances in Consumer Research, 33, p. 131-133.

Ryan, A. M. (2001). The peer group as a context for the development of young adolescence motivation and achievement. Child Development, 72 (4), p.11351150

Setiana, R. 2013. Waspadai gaya hidup konsumtif dan shopaholic!. 20 April 2013. http://mjeducation.co/waspadai-gaya-hidup-konsumtif-dan-shopaholic/

Servidioa, R., Ambra Gentileb, A., \& Bocab, S. (2018). The mediational role of coping strategies in the relationship between self-esteem and risk of internet addiction. Europe's Journal of Psychology, 14(1), 176-187. Doi:10.5964/ejop.v14i1.1449

Sharma, B., Raciti, M., O’Hara, R. \& Reinhard, K. (2013). A tri-country social marketing study of young university women's alcohol consumption and the perceived 
influence of their peers' attitudes. e-Journal of Social and Behavioral Research in Bussiness, 4 (1), p. 1-11. http://www.esjbrb.org

Shareef, M.A., Dwivedi, Y.K., \& Kumar, V. (2016). Mobile marketing channel online consumer behavior. Switzerland: Springer International Publishing. Doi:10.1007/978-3-319-31287-3

Shrestha, T. (2013). Self-esteem and stress coping among proficiency certificate level nursing students in nursing campus Maharajgunjand LalitpurNursing Campus. $J$ Nepal Health Res Counc, 11(25), 283-288

Suryabrata, S. (2012). Metodologi penelitian. Jakarta: PT. RajaGrafindo Persada.

Undheim, A. M. \& Sund, A. M. (2017). Associations of stressful life events with coping strategies of 12-15-year-old Norwegian adolescents. Eur Child Adolesc Psychiatry, Doi: 10.1007/s00787-017-0979-x

Ureta, I.G. (2007). Addictive buying: causes, processes, and symbolic meanings, thematic analysis of a buying addict's diary. The Spanish Journal of Psychology, 10 (2), 408-422. ISSN 1138-7416 